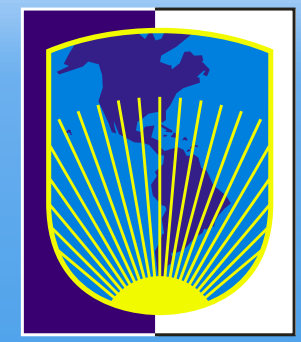

RE2-06-004

Economic and Sector Study Series

\title{
OPENNESS AND THE INTERNATIONAL ALLOCATION OF FOREIGN DIRECT INVESTMENT
}

Manuel R. Agosin Roberto Machado

BELIZE

COSTA RICA

DOMINICAN REPUBLIC

EL SALVADOR

GUATEMALA

HAITI

HONDURAS

MEXICO

NICARAGUA

PANAMA 
This document in discussion is not an official publication of the Inter-American Development Bank. The purpose of the Economic and Sector Study is to provide a mechanism for diffusion of selected analytical work undertaken by the department in support of its operational program at the country or sub-regional level. Opinions and judgments expressed in these studies do not necessarily reflect the view of Bank Management or member countries. 


\title{
PREFACE
}

This paper, written by Manuel R. Agosin, Regional Economic Advisor to the Department, and Roberto Machado, economist in the REA's office, develops an ordinal index to measure the openness of FDI policy regimes for individual developing and developed countries. It finds that there has been a generalized increase in the degree of openness to FDI in the world between 1990 and 2002. Whereas openness to FDI is positively associated with FDI flows, the most important determinants of variations in FDI flows across countries and over time are country size, the level of educational achievement, and growth. Liberalizing approval procedures and lifting requirements that foreign companies enter into joint ventures with domestic firms are the most important components of a liberalization policy that seeks to encourage FDI.

The paper concludes that the openness of the FDI regime operates as a factor enabling FDI, but that location advantages are paramount in determining the international allocation of FDI. The authors then turn the question around and ask what countries are more likely to impose restrictions on FDI. They find that lower levels of education and larger domestic markets are associated with greater restrictions on FDI. In addition, there is some evidence that better institutions are associated with lower FDI restrictions.

These results are very relevant to countries served by our Regional Department. All of them, including Mexico, have very open FDI regimes. However, the degree to which they have been able to attract FDI varies widely from one country to another. This points to the importance of strengthening the attractiveness of the domestic economy, and not merely opening up the economy to investment.

As regards Central America, the importance of country size for FDI points to the need to widen markets, mainly through a deeper and more complete integration within the Central American region. The free trade agreement between Central America, the Dominican Republic and the United States (CAFTA-DR) should work in the same direction. The two other factors favorable to the attraction of FDI identified in the empirical analysis (an educated labor force and high-quality institutions) also need strengthening in all the countries served by our Department.

A special word of thanks to Miriam Perez-Fuentes, who is responsible for the physical production of this series.

\author{
Máximo Jeria \\ Manager \\ Regional Operations Department II \\ Central American Isthmus, Mexico, Haiti and Dominican Republic
}

Washington, DC, January 2006 


\section{TABLE OF CONTENTS}

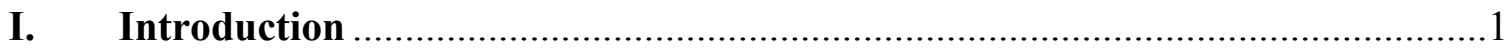

II. Degree of Openness of FDI Regimes and Liberalizing Trends ......................2

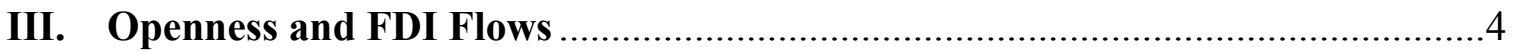

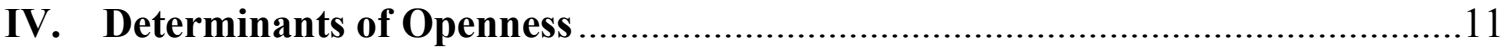

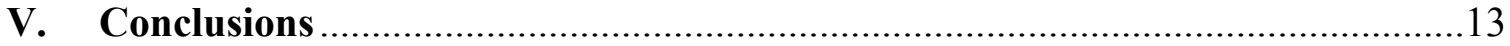

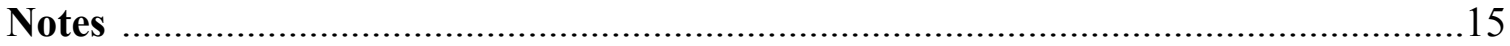

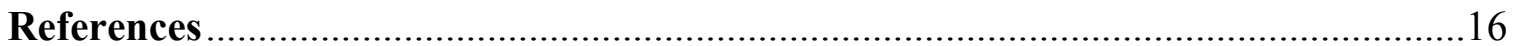

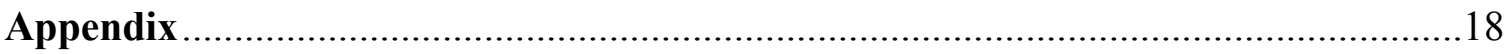




\section{Openness and the International Allocation of Foreign Direct Investment ${ }^{*}$}

\section{Introduction}

Over the past couple of decades, perceptions in developing countries as to the benefits and costs of foreign direct investment (FDI) have changed dramatically. Up until well into the 1980s, the prevailing view was that FDI entailed a loss of control over key sectors of the economy. Therefore, it was thought that, rather than allowing multinational enterprises (MNEs) unfettered free access to the economy, it was preferable to "unpackage" FDI and purchase its components (technology, management know-how, brand names, etc) separately without relinquishing control. These policies were successful in fostering development and industrialization in some countries (principally the countries in East Asia that practiced restrictive policies - e.g., South Korea and Thailand), but were much less successful in other countries, where they wound up simply scaring off potential investors without necessarily encouraging domestic ones.

The pendulum has swung in the opposite direction. Now the conventional wisdom among policy makers and interested observers is that liberalization is the best approach to obtaining access to the intangible benefits that come with FDI and the presence of MNEs. Beginning in the mid 1980s, one developing country after another has liberalized its investment regime.

One problem for analysts in assessing the results of this change in attitudes toward MNEs in terms of attracting FDI is that we do not have a reliable measurement of FDI regime openness. We do not know the extent to which the change in attitudes has led to real policy changes. Therefore, there is no objective basis for (a) comparing countries according to the degree of openness of their policy regimes and (b) determining whether, in fact, liberalization has taken place over time in individual countries. UNCTAD's World Investment Reports tally each year the number of liberalizing measures and the number of more restrictive measures taken in developing countries as a whole. ${ }^{1}$ Liberalizing measures have been outnumbering by far the introduction of greater restrictions. However, the reports are silent on how liberal the policy regimes of individual countries really are and how they have been changing over time.

We tackle this issue in this paper. In section II we propose an ordinal index of the degree of openness of FDI regimes, which we measure for 111 countries, both developed, developing, and in transition. We show the evolution of the index between 1990, 1996, and 2002 in three developing regions (Africa, Asia and Latin America), in transition economies, and in developed countries. ${ }^{2}$ Section III presents the result of a simple econometric exercise that attempts to explain the variation across countries and time periods of FDI inflows in

\footnotetext{
${ }^{*}$ The authors wish to thank Roberto Alvarez, Gregory Corcos, two anonymous referees, and the participants in the annual LACEA meeting in November 2004 for useful comments and suggestions on an earlier draft. We are particularly indebted to our departed friend Sanjaya Lall for his thoughtful comments and dedicate this paper to his memory.
} 
1990, 1996, and 2002 using five explanatory variables: country size, human capital stock, growth rate of GDP, the index of FDI openness, and institutional quality. In order to ascertain whether there is a relationship between FDI inflows (normalized by GDP size) and the openness of FDI regimes, we also undertake equality of means tests for the indices for countries with above-median FDI/GDP ratios and for countries with below-median ratios. Section IV explores the factors that explain the probability that a country will resort to restrictions on FDI. The final section concludes.

\section{Degree of Openness of FDI Regimes and Liberalizing Trends}

As already noted, no systematic effort has yet been made to categorize national investment regimes according to their degree of openness. This is clearly a difficult task, because regimes that appear to be liberal on paper may not be so in practice, as officials may exercise a great deal of discretion. The opposite is also true: regimes that are restrictive in practice may be operated in a rather liberal fashion, because of bureaucratic ineptness or because the restrictions are sometimes unenforceable. Also, the importance that foreign investors attach to the different characteristics of an investment regime may vary quite considerably between firms. We tackle this issue later in the paper. Keeping these caveats in mind, an attempt is made here to construct an ordinal indicator of the degree of openness and to apply it to countries for which the requisite information is available. The raw information is from the IMF's Exchange Arrangements and Exchange Restrictions Annual Report. The following five criteria were used in building the index:

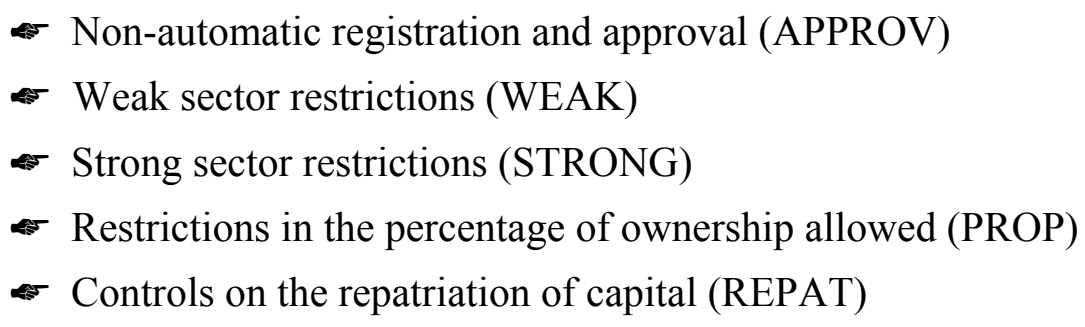

For each one of these criteria, a score of zero is indicative of the existence of a restriction, a score of one of the absence of any restriction. If strong sector restrictions are in force, the country scores 0 on account of WEAK and an additional 0 on account of STRONG. It should also be noted that the index does not include other factors which cannot be verified for a large number of countries but which also have a bearing on how liberal or open an FDI regime is in practice (the existence of corruption, for example). Some of these are incorporated into the indicators of the quality of governance that are used below in the econometric analysis.

The scores for all five criteria are added up to constitute a country's openness index. Maximum openness is equal to 5, maximum restrictiveness receives a score of zero. There was a clear worldwide trend towards liberalization in 1990-2002. The unweighted mean index for all countries included in the sample rises from 2.46 in 1990 to 3.43 in 1996 and to 3.85 in 2002 (see Table 1). Most of this increase in the openness index took place between 1990 and 1996, whereas between 1996 and 2002 the increase was much more moderate. Equality of means tests reveal that these averages are statistically different at standard levels of significance, which confirms the importance of the liberalization trend. It should be noted that no single country in the sample prohibits FDI and practically all claim to welcome it. 


\section{Table 1}

Openness Index in 1990, 1996, and 2002

\begin{tabular}{|c|c|c|c|c|c|c|}
\hline & $\begin{array}{c}\text { All } \\
\text { countries }\end{array}$ & Africa & $A s i a^{a}$ & $\begin{array}{c}\text { Latin } \\
\text { America }\end{array}$ & $\begin{array}{l}\text { Transition } \\
\text { economies }\end{array}$ & $\begin{array}{c}\text { Developed } \\
\text { countries }\end{array}$ \\
\hline \multicolumn{7}{|l|}{ Index 1990} \\
\hline Mean & 2.46 & 2.00 & 1.69 & 2.81 & 1.00 & 3.36 \\
\hline Median & 3.00 & 2.00 & 1.50 & 3.00 & 1.00 & 3.50 \\
\hline Standard dev. & 1.53 & 1.27 & 1.49 & 1.40 & 0.82 & 1.50 \\
\hline Countries & $93^{\mathrm{b}}$ & 27 & 16 & 21 & 4 & 22 \\
\hline \multicolumn{7}{|l|}{ Index 1996} \\
\hline Mean & 3.43 & 2.93 & 2.50 & 3.95 & 3.52 & 4.00 \\
\hline Median & 4.00 & 3.00 & 2.00 & 4.00 & 4.00 & 4.00 \\
\hline Standard dev. & 1.39 & 1.39 & 1.71 & 1.07 & 1.33 & 0.93 \\
\hline Countries & $111^{\mathrm{b}}$ & 28 & 16 & 21 & 21 & 22 \\
\hline \multicolumn{7}{|l|}{ Index 2002} \\
\hline Mean & 3.85 & 3.68 & 3.38 & 3.95 & 4.05 & 4.00 \\
\hline Median & 4.00 & 4.00 & 4.00 & 4.00 & 4.00 & 4.00 \\
\hline Standard dev. & 1.21 & 1.31 & 1.54 & 1.12 & 0.92 & 1.15 \\
\hline Countries & $111^{\mathrm{b}}$ & 28 & 16 & 21 & 21 & 22 \\
\hline \multicolumn{7}{|l|}{ Difference in means $\mathrm{s}^{\mathrm{c}}$} \\
\hline 1990-1996 & Yes & Yes & No & Yes & Yes & No \\
\hline 1996-2002 & Yes & Yes & No & No & No & No \\
\hline $1990-2002$ & Yes & Yes & Yes & Yes & Yes & No \\
\hline
\end{tabular}

Source: Own calculations.

${ }^{a}$ Excluding Japan, which is included in the developed countries group.

${ }^{\mathrm{b}}$ The sum of the countries in each group does not add up to the total number of countries, which includes some Middle Eastern countries.

${ }^{c}$ Test of equality of means. "Yes" means that the test rejects the hypothesis of equality of means at least at the 5 per cent level.

As regards regional averages, in 1990 the highest was, as expected, the average for developed countries. Interestingly, in 1996, and again in 2002, Latin America scored almost as high as developed countries. In this latter year, the transition economies recorded a marginally higher index than that of the developed countries. A statistically significant rise in mean openness can be observed in Latin America and the transition economies between 1990 and 1996, whose means rose from 2.81 to 3.95, and from 1.00 to 3.52, respectively. Likewise, there was a statistically significant increase in Africa's mean openness index between 1990 and 1996 and between 1996 and 2002. In the case of Asia, the cumulative change between 1990 and 2002 was significant, even if the changes in the sub-periods 19901996 and 1996-2002 were not, indicating more gradual but nonetheless unmistakable liberalization. These results are consistent with the profound liberal reforms implemented in most countries throughout these regions since early 1990s.

Has the index of openness varied as between different regions? In 1990, Asia's and Africa's indices were lower, and significantly so, than those of Latin America and the developed countries (see Table 2). The difference in the mean indices of Asia and Africa, on the other hand, was not statistically significant. At the same time, the Latin American average index was lower but not significantly different from that of developed countries. The policies 
of developed countries in this respect can be considered as a sort of benchmark against which to measure the degree of openness in developing countries, since the former have commitments in the OECD to maintain open FDI regimes.

Table 2

Difference in Regional Means of Openness Index in 1990, 1996, and 2002 ( $t$ values)

\begin{tabular}{|l|c|c|c|}
\hline \multicolumn{1}{|c|}{ Equality of means test } & Index 1990 & Index 1996 & Index 2002 \\
\hline Africa-Asia & 0.27 & 0.12 & 0.00 \\
Africa-Latin America & $2.11^{* *}$ & $3.29 * * *$ & 1.02 \\
Asia-Latin America & $2.02 *$ & $2.44 * *$ & 0.90 \\
Africa-Developed countries & $3.96 * * *$ & $3.71 * * *$ & 1.12 \\
Asia-Developed countries & $3.84 * * *$ & $2.90 * * *$ & 1.12 \\
Latin America-Developed countries & 1.07 & 0.15 & 0.27 \\
\hline
\end{tabular}

Source: Own calculations.

* Rejects the null hypothesis of equality of means at the 10 per cent level.

** Rejects the null hypothesis of equality of means at the 5 per cent level.

*** Rejects the null hypothesis of equality of means at the 1 per cent level.

By 1996, the situation was quite different. As already noted, all the five groups of countries recorded increases in their average openness indices between 1990 and 1996, but the increase was statistically significant only in Africa, Latin America and transition economies, where the most far-reaching policy changes have taken place since the early 1990s. In 1996, the average openness index was statistically higher in Latin America than in either Africa or Asia. As in 1990, in 1996 Latin America's mean openness index was not statistically different from the mean for developed countries. This changed in 2002, when all country group average indices were not statistically different from each other. This can be interpreted as an inter-regional convergence towards open FDI regimes.

\section{Openness and FDI Flows}

Is liberalization of the FDI regime conducive to larger flows of FDI? We examined this issue with the aid of an econometric model explaining the inter-country variation of FDI inflows in 1990, 1996, and 2002. The empirical model is compatible with Dunning's "eclectic paradigm" for explaining FDI as the result of the existence of (1) ownership-specific, intangible assets of MNEs; (2) difficulties in exploiting such assets through arm's-length transactions, and (3) locational advantages in recipient countries that induce MNEs to invest in them [Dunning, 1981 and 1988; Caves, 1996]. Since we are looking at the international distribution of FDI inflows, the accent is on the locational advantages of host countries.

In line with Dunning's framework, MNEs can have various types of motivations for deciding on the location of FDI in particular host countries. Broadly, MNE investment can be classified into the following types:

- It can be market-seeking. MNEs engaging in this kind of investment will focus on countries with large domestic markets. Market-seeking investment may respond to trade barriers that discourage exporting to the target country. But even in the absence of such barriers MNEs may choose to invest in target markets rather than 
export to them: transportation costs may be high, products may need to be adapted to the particular tastes of consumers, after-sales service may be an important dimension of remaining competitive. Many of these activities have economies of scale, which means that more market-seeking investment will take place in countries with big domestic markets than in countries with small ones.

- Good growth prospects may also attract market-seeking investment. Rapidly growing economies are also expected to have expanding domestic markets.

- Other MNEs may be natural-resource seeking. Investment in many developing countries is of this nature. The relative abundance of minerals is probably a good proxy for this factor.

- Some MNEs may seek low unit labour costs. Investments in assembly of electronic products, toys, or clothing, in export processing zones or elsewhere, is of this nature.

- MNEs producing more technologically sophisticated products are human capitalseeking. These investments are in more complex industries. The incentive for FDI is the availability of low-cost skilled workers (in sectors such as software or pharmaceuticals).

Caves and Dunning's framework for analyzing the variables that account for FDI is corroborated by recent theoretical and empirical research at the firm level which shows that both large domestic markets and differences in factor endowment between home and host countries are important variables impinging on the MNE decisions as to where to locate production [see Hanson, Mataloni and Slaughter, 2001; Yeaple, 2003a; Yeaple 2003b].

It is not possible to capture all of these dimensions in econometric analysis. In the results that are presented below, the dependent variable is the natural log of FDI in US dollars deflated by the price index of capital equipment in the United States (lnFDI). We use the following explanatory variables: lnGDP, the natural log of GDP in US dollars in 1995 prices, a proxy for market-seeking investment; EDU, UNDP's education index, ${ }^{3}$ a proxy for the availability of human capital and/or skilled labour in host economies [see UNDP, 2002]; $\mathrm{XMIN}$, the share of minerals and fuels in total exports, which proxies natural resource availability; and GROWTH, the rate of growth of real GDP in the current and previous five years, which we use as a proxy for growth prospects. Except for EDU and the price index of capital equipment in the United States, data for all variables comes from the World Bank's World Development Indicators.

These factors are our control variables. We also add the openness index, in order to test for the hypothesis that countries that have open investment regimes attract more FDI than countries with restrictive regimes, after having controlled for the structural determinants of FDI. 
The results of the estimations with panel data are shown in Table 3. All equations use data for both developed and developing countries and for economies in transition. The results are generally consistent with the eclectic theory of MNE investment. ${ }^{4}$ The different models were estimated using alternatively pooled OLS, fixed effects (within), and random effects. As the qualitative results are similar, Table 3 shows the results obtained with the latter estimation method.

Table 3

Explaining the Inter-Country Variation of FDI in 1990, 1996, and 2002 Panel Data Estimation

(Dependent variable: InFDI; Random effects method)

\begin{tabular}{|c|c|c|c|c|c|}
\hline & (1) & (2) & (3) & (4) & (5) \\
\hline $\operatorname{lnGDP}$ & $\begin{array}{c}0.78 \\
(13.36)^{* * *}\end{array}$ & $\begin{array}{c}0.80 \\
(13.70)^{* * *}\end{array}$ & $\begin{array}{c}0.70 \\
(11.40)^{* * *}\end{array}$ & $\begin{array}{c}0.72 \\
(11.50)^{* *}\end{array}$ & $\begin{array}{c}0.71 \\
(11.70)^{* * *}\end{array}$ \\
\hline EDU & $\begin{array}{c}3.48 \\
(6.11)^{* * *}\end{array}$ & $\begin{array}{c}3.14 \\
(5.11)^{* * *}\end{array}$ & $\begin{array}{c}2.81 \\
(4.57)^{* * *}\end{array}$ & $\begin{array}{c}2.58 \\
(3.98)^{* * *}\end{array}$ & $\begin{array}{c}3.09 \\
(5.28)^{* * *}\end{array}$ \\
\hline GROWTH & $\begin{array}{c}6.73 \\
(3.50)^{* * *}\end{array}$ & $\begin{array}{c}6.71 \\
(3.61)^{* * *}\end{array}$ & $\begin{array}{c}6.49 \\
(3.34)^{* * *}\end{array}$ & $\begin{array}{c}6.55 \\
(3.49)^{* * *}\end{array}$ & $\begin{array}{c}6.79 \\
(3.61)^{* * *}\end{array}$ \\
\hline INDEX & & $\begin{array}{c}0.10 \\
(1.65)^{*}\end{array}$ & & $\begin{array}{c}0.09 \\
(1.49)\end{array}$ & \\
\hline INST & & & $\begin{array}{c}0.40 \\
(2.78)^{* * *}\end{array}$ & $\begin{array}{c}0.36 \\
(2.54)^{* *}\end{array}$ & \\
\hline INDEX*INST & & & & & $\begin{array}{c}0.08 \\
(2.56)^{* *}\end{array}$ \\
\hline R-squared & 0.68 & 0.68 & 0.66 & 0.66 & 0.66 \\
\hline Wald (joint) $\chi^{2}(k)$ & $491.0 * * *$ & $502.7 * * *$ & $497.9^{* * *}$ & $508.4 * * *$ & $507.2 * * *$ \\
\hline Number of countries & 103 & 103 & 102 & 102 & 102 \\
\hline Number of observations & 275 & 274 & 268 & 267 & 267 \\
\hline
\end{tabular}

Source: Authors' own calculations.

$\mathrm{t}$-values in parenthesis.

* significant at the $10 \%$ level, $* *$ significant at the $5 \%$ level, $* * *$ significant at the $1 \%$ level.

Note: All equations include developed and developing countries and transition economies using robust standard errors.

Definition of variables: EDU = UNDP education index; GROWTH = average rate of growth of GDP in 1984-90 for 1990, in 1991-96 for 1996, and 1997-2002 for 2002; INDEX = FDI openness index; INST = institutional quality index; INDEX*INST = INDEX multiplied by INST. FDI is in U.S. dollars at current prices and GDP is in U.S. dollars at 1995 prices.

Data sources: FDI: United Nations Conference on Trade and Development (UNCTAD), World Investment Report, 2003, Geneva; EDU: United Nations Development Programme (UNDP), Human Development Report, 2002, New York; FDI, GDP, GROWTH, and MINX: World Bank, World Development Indicators, 2004, Washington, DC. 
The structural determinants of FDI inflows appear to be $\operatorname{lnGDP}$, EDU, and GROWTH. In all equations, the elasticity of FDI to GDP falls in the range of $0.7-0.8 .^{5}$ The high significance of the coefficient attached to lnGDP confirms the market-seeking behaviour of MNEs. The results also lend credence to the hypothesis that human capital availability is important for the FDI decisions of MNEs. The proxy for human capital, EDU, is highly significant. The elasticity of FDI flows with respect to educational attainment is very high. Here we estimate it in the range of 1.9-2.6, depending on the specification of the model: ${ }^{6}$ a 10 per cent increase in the education index is associated with an increase between 19 and 26 percentage points in FDI flows. Such is the difference in the educational index observed, say, between Ecuador and Korea, or between Bolivia and Singapore. Finally, MNEs appear to have a strong preference for dynamic economies. Surprisingly, XMIN was not statistically significant at conventional significance levels, and it even appeared with negative sign in some specifications of the model.

Each specification of the model explains around two thirds of the variation of FDI inflows, and all three structural control variables show the expected signs and are significant at the 1 per cent level. Equation (1) shows the basic structural model. In equation (2), the FDI openness index (INDEX) is included. In equation (3), we replace the openness index by an index of institutional quality and governance (INST) which considers voice and accountability, political stability, government effectiveness, regulatory quality, rule of law, and control of corruption [see Kaufmann, Kraay, and Mastruzzi, 2003]. ${ }^{7}$ Equation (4) shows the results when we include both INDEX and INST. In order to capture the interaction between the openness of FDI regimes and the quality of institutions, in equation (5) both variables are replaced by their product (INDEX*INST).

Our openness indicator is neither significant at standard levels nor does it add much to the explanatory power of the equation. Things improve when we add the quality of institutions variable (INST, in equation (3)). By contrast, INST is significant whether one puts it into an equation by itself (equation (3)) or together with the openness index (equation (4)). However, judging by the R-square, which remains practically unchanged when INST is added, its inclusion does not improve the explanatory power of the basic model. The results of adding the interaction of openness and institutional quality are almost identical as those obtained by adding institutions alone. What this may be telling us is that good institutions are likely to be associated with open FDI policies, so that the key variable is not the kind of FDI regime a country has but the quality of its institutions.

We also ran a regression for developing countries alone. Surprisingly, the results are almost identical to those obtained for all countries, including the non-relevance of the natural resources abundance variable (XMIN).

In an attempt to explore the relative explanatory power of the five different components of the FDI openness index, we included each of them one at a time in the econometric model. For the whole sample, the most important sub-indices are the absence of restrictions in the percentage of foreign ownership allowed (PROP) and automatic registration and approval (APPROV), both of which are statistical significant, have the expected signs, and add marginally to the explanatory power of the basic model. The results 
are shown in Table 4. All other sub-indices turned out not to be significant at all. This also holds when the institutional quality variable is included. Moreover, the estimated coefficient associated with PROP and APPROV are almost four times as high as those reported in Table 3 for INDEX.

Table 4

Explaining the Inter-Country Variation of FDI In 1990, 1996, AND 2002 Panel Data Estimation

(Dependent variable: InFDI; Random effects method)

\begin{tabular}{|c|c|c|c|c|c|}
\hline & (1) & (2) & (3) & (4) & (5) \\
\hline InGDP & $\begin{array}{c}0.79 \\
(13.80)^{* * *}\end{array}$ & $\begin{array}{c}0.71 \\
(11.60)^{* * *}\end{array}$ & $\begin{array}{c}0.79 \\
(14.00)^{* * *}\end{array}$ & $\begin{array}{c}0.71 \\
(11.70)^{* * *}\end{array}$ & $\begin{array}{c}0.80 \\
(14.00)^{* * *}\end{array}$ \\
\hline EDU & $\begin{array}{c}3.35 \\
(5.89)^{* * *}\end{array}$ & $\begin{array}{c}2.77 \\
(4.55)^{* * *}\end{array}$ & $\begin{array}{c}3.16 \\
(5.44)^{* * *}\end{array}$ & $\begin{array}{c}2.61 \\
(4.21)^{* * *}\end{array}$ & $\begin{array}{c}3.10 \\
(5.31)^{* * *}\end{array}$ \\
\hline GROWTH & $\begin{array}{c}6.66 \\
(3.60)^{* * *}\end{array}$ & $\begin{array}{c}6.51 \\
(3.50)^{* * *}\end{array}$ & $\begin{array}{c}6.80 \\
(3.66)^{* * *}\end{array}$ & $\begin{array}{c}6.64 \\
(3.54)^{* * *}\end{array}$ & $\begin{array}{c}6.68 \\
(3.62)^{* * *}\end{array}$ \\
\hline INST & & $\begin{array}{c}0.36 \\
(2.52)^{* *}\end{array}$ & & $\begin{array}{c}0.35 \\
(2.50)^{* *}\end{array}$ & \\
\hline PROP & $\begin{array}{c}0.42 \\
(2.41)^{* *}\end{array}$ & $\begin{array}{c}0.40 \\
(2.33)^{* *}\end{array}$ & & & $\begin{array}{c}0.34 \\
(1.90)^{*}\end{array}$ \\
\hline APPROV & & & $\begin{array}{c}0.33 \\
(2.19)^{* *}\end{array}$ & $\begin{array}{c}0.30 \\
(1.96)^{* *}\end{array}$ & $\begin{array}{c}0.25 \\
(1.63)^{*}\end{array}$ \\
\hline R-squared & 0.69 & 0.66 & 0.69 & 0.67 & 0.69 \\
\hline Wald (joint) $\chi^{2}(k)$ & $505.6^{* * *}$ & $511.5 * * *$ & $517.4 * * *$ & $518.8 * * *$ & $518.5^{* * *}$ \\
\hline Number of countries & 103 & 102 & 103 & 102 & 103 \\
\hline Number of observations & 274 & 267 & 274 & 267 & 274 \\
\hline
\end{tabular}

Source: Authors' own calculations.

t-values in parenthesis.

* significant at the $10 \%$ level, ** significant at the $5 \%$ level, *** significant at the $1 \%$ level.

Note: All equations include developed and developing countries using robust standard errors.

Definition of variables: PROP $=$ restrictions on the percentage of foreign ownership allowed (no restrictions $=1$, restrictions $=0$ ); APPROV $=$ automatic registration and approval of FDI (automatic approval $=1$, screening $=0$ ).

Of all the aspects of the investment regime, the most important ones from the vantage points of their impact on the volume of FDI are the approval procedures and the percentage of foreign ownership allowed. Countries using automatic approval mechanisms once certain conditions are met, and which do not screen investments, can expect to attract larger flows of FDI. Also, countries that do not impose joint venture restrictions on foreign investors are likely to be more successful in attracting FDI than countries that do resort to these measures. Coefficients do not change much when both dummy variables are entered together into the equation, although they are significant only at the 10 percent level. This result may be the result of the fact that countries that screen individual investments may also impose joint venture requirements on foreign investors. 
Other aspects of investment policies do not matter much. Sector restrictions to investment do not seem to deter FDI; surprisingly, neither do controls on the repatriation of capital or on profit remittances. One could rationalize these results. It could be that sectors that are out of bounds to multinationals would not have attracted investments anyway. The informatics policy in Brazil in the 1980s, which severely restricted foreign investment in the information technology sector, readily comes to mind. In today's environment, controls on capital repatriation or on profit remittances are likely to be ineffective, because they can be gotten around through transfer pricing and the use of derivatives markets such as currency swaps.

In order to find out whether there have been changes in the determinants of FDI inflows over time, we ran regressions for 1990, 1996, and 2002 individually. Whenever we rejected the null hypothesis of homoskedastic disturbances with the White test either with or without cross products, we used heteroskedasticity-consistent standard errors to compute the $\mathrm{t}$-values of the estimated parameters. The openness index for individual years loses all significance, and the institutional quality variable continues to be highly significant, either alone or interacted with the openness index in 1990 and 2002 (results available on request).

The main conclusions of the empirical work described here are:

i. the basic model explains between two thirds and 81 per cent of inter-country variations in FDI inflows;

ii. the three structural explanatory variables are statistically very significant;

iii. the elasticity of FDI to GDP changes ranges between 0.5 and 0.9 and is increasing over time, implying that host market effects are of growing importance;

iv. the estimated coefficient associated with the growth rate falls sharply between 1990 and 1996 and recovers partially in 2002;

v. the institutional quality index, a highly significant variable, contributes marginally to the overall explanatory power of the equation;

vi. institutional quality is more significant in 2002, and makes a larger contribution to the goodness of fit, than in the two earlier years, with the implication that the importance of good institutions may well be growing;

vii. the FDI openness index adjusted for institutional quality is statistically significant, but FDI openness is only marginally so, probably because good institutions are associated with open FDI regimes;

viii. the two restrictions that appear to be most damaging to FDI inflows are those that force investors to enter into joint ventures with domestic partners and complex, non-automatic approval procedures.

From these conclusions we derive a number of reflections. In the first place, it would seem that the size of the domestic market is not only a key determinant of FDI but also one that is growing in importance. Thus the extraordinary growth of FDI into China could continue or even accelerate accelerate. Although much of FDI inflows into China in recent years has been for export markets, one can expect that this will change in the near future, as massive rural-urban migration, large remittances to rural areas, and more policy attention to rural development cause the Chinese domestic market to continue expanding vigorously. 
The importance of domestic market size also sheds a new light on the worldwide proliferation of free trade agreements in recent years. Insofar as they increase market size, they may be important in attracting FDI. Since May $1^{\text {st }}, 2004$, the relevant domestic market for the 10 new members of the European Union has expanded significantly. To a lesser extent, a similar trend can be seen in the Americas, with the efforts to join MERCOSUR and the Andean Community, and the coming into effect at the beginning of January 2006 of the CAFTA-DR (the Central American Free Trade Agreement between five countries in Central America plus the Dominican Republic, and the United States).

Second, we find that institutional quality has a growing importance in explaining FDI allocation by MNEs. However, it should be noted that the quantitative importance of this variable is quite a bit lower than what is suggested by research into the relationship of growth and investment, on the one hand, and institutional quality, on the other [see Knack and Keefer, 1995; Burki and Perry, 1998; Agosin and Machado, forthcoming].

Third, does the finding that our FDI openness index is not important in explaining variations in FDI across countries or across time periods imply that FDI regimes do not matter to investment decisions of MNEs? Clearly, having an open investment regime is not enough to attract FDI: most developing countries and transition economies by 2002 had very liberal investment regimes but continue to receive little FDI. Witness Bolivia, Côte d'Ivore, Hungary, Nicaragua, Syria, Tajikistan, and Uganda: they all score five on the openness index, but, with the exception of Hungary, receive little FDI.

Nonetheless, it remains true that, in order to attract FDI, countries do need to open up their investment regimes. This ought to be viewed as an enabling policy. It cannot substitute for location advantages. However, countries that have important location advantages but have restrictive investment policies receive little FDI. There are many examples: Korea, prior to the Asian crisis; Japan, until very recently (in relation to the size of its economy); China, before 1979.

There is some evidence that openness to FDI has enabled the forces of location to go to work. Samples of 55 to 84 developing countries and transition economies for which data were available were divided into two sub-samples in 1990, 1996, and 2002, one with countries whose average FDI/GDP ratio exceeded the median of the sample, and the other with countries with below median FDI/GDP ratios (see Table 5). Low FDI developing countries (i.e. countries with below-median ratios) made important changes in their policy regimes, and their mean FDI openness index shows a statistically significant increase both between 1990 and 1996 and between 1996 and 2002. In the case of high FDI developing countries (countries above the developing world median FDI/GDP ratio), the increase in the FDI openness index was statistically significant only between 1990 and 1996. Taking the whole 1990-2002 period, in both groups of countries the increase in the openness indices was statistically significant, confirming the openness trend observed since 1990.

It is also worth noting that both groups of countries do not show average openness indices statistically different from each other in either year, indicating that high and low FDI countries have had similar policy regimes towards FDI in 1990, 1996, and 2002. Indeed, the median openness indices for both groups were identical in 1996 and 2002. Notwithstanding, 
low-FDI developing countries opened up their FDI regimes more than high-FDI countries: between 1990 and 2002, in the former the average index rose by 1.91 points (103 percent), whereas in the latter it did so by 1.28 points (50 per cent). This shows a trend towards convergence to open FDI regimes among developing countries and transition economies.

Table 5

Developing Countries and Transition Economies:

Openness Index for Countries with Above-Median and Below-Median FDI-To-GDP Ratios

\begin{tabular}{|l|c|c|c|}
\hline \multicolumn{1}{|c|}{ Country groups } & Index 1990 & Index 1996 & Index 2002 \\
\hline High FDI countries $^{\mathbf{a}}$ & & & \\
Mean & 2.55 & 3.43 & 3.83 \\
Median & 3.00 & 3.00 & 4.00 \\
Standard deviation & 1.43 & 1.36 & 41 \\
Countries & 29 & & \\
& & & 3.76 \\
Low FDI Countries & & 3.07 & 4.00 \\
Mean & 1.85 & 3.00 & 41 \\
Median & 2.00 & 1.54 & \\
Standard deviation & 1.32 & 42 & \\
Countries & 26 & & \\
& & & \\
Difference in means & & & \\
High-Low 1990 & No & & \\
High-Low 1996 & No & & \\
High-Low 2002 & No & & \\
High 1990-1996 & Yes & & \\
Low 1990-1996 & Yes & & \\
High 1996-2002 & No & & \\
Low 1996-2002 & Yes & & \\
High 1990-2002 & Yes & & \\
Low 1990-2002 & Yes & & \\
\hline
\end{tabular}

Source: Own calculations.

${ }^{a}$ Countries with FDI/GDP ratios above median for developing countries.

${ }^{\mathrm{b}}$ Countries with FDI/GDP ratios below median for developing countries.

${ }^{\mathrm{c}}$ Test of equality of means ( 5 per cent level of significance).

\section{Determinants of Openness}

In this section, we explore which kinds of countries are more likely to impose restrictions on FDI. There are two possible outcomes. Under Hypothesis I, countries with more favourable location assets may be more prone to impose restrictions on FDI, because FDI may well flow to them with or without restrictions. Therefore, they may be more successful in their attempts to steer FDI in specific directions or to impose restrictions in favour of joint ventures without the fear of alienating MNEs. Hypothesis II is that certain location advantages such as highly skilled labour or good institutions tend to be correlated with liberal FDI policies. In other words, liberal FDI regimes are part and parcel of development and modernization. 
In order to see which one of these hypotheses holds up to the empirical data, we estimated a binomial logit model for each component of the FDI openness index: weak sector restrictions (WEAK); strong sector restrictions (STRONG); controls on the repatriation of capital (REPAT); restrictions in the percentage of foreign ownership allowed (PROP); and non-automatic registration and approval (APPROV). The model estimates the probability that the country will be open in each one of these dimensions of liberalization, and explains this probability by recourse to lnGDP, EDU and INST as independent variables. The results are shown in Table 6.

Table 6

Explaining the Probability of Liberalization, by Component of the FDI Openness Index

(Dependent variables: WEAK; STRONG; REPAT; PROP, and APPROV; Binomial logit estimation)

\begin{tabular}{|l|c|c|c|c|c|}
\hline & WEAK & STRONG & REPAT & PROP & APPROV \\
\hline EDU & 1.67 & 6.49 & 4.52 & 1.55 & 4.07 \\
& $(1.95)^{*}$ & $(4.55)^{* * *}$ & $(4.91)^{* * *}$ & $(1.71)^{*}$ & $(4.29)^{* * *}$ \\
INST & 0.52 & 0.23 & 0.11 & 0.47 & 0.51 \\
& $(2.58)^{* * *}$ & $(0.69)$ & $(0.49)$ & $(2.03)^{* *}$ & $(2.55)^{* *}$ \\
InGDP & -0.55 & -0.71 & -0.02 & -0.22 & -0.25 \\
& $(-6.06)^{* * *}$ & $(-5.18)^{* * *}$ & $(-0.27)$ & $(-2.37)^{* *}$ & $(-2.97)^{* * *}$ \\
Test $\chi^{2}$ (k) & $44.44 * * *$ & $43.13 * * *$ & $52.91 * * *$ & $12.31 * * *$ & $49.31 * * *$ \\
Number of & & & & & 297 \\
observations & 297 & 297 & 297 & 297 & 29 \\
\hline
\end{tabular}

Source: Own calculation.

$\mathrm{t}$-values in parenthesis.

* significant at the $10 \%$ level, ** significant at the $5 \%$ level, *** significant at the $1 \%$ level.

Definition of variables: WEAK $=$ weak sector restrictions; STRONG $=$ strong sector restrictions; REPAT $=$ controls on the repatriation of capital; PROP $=$ index of restrictions in the percentage of foreign ownership allowed; APPROV = index of automatic registration and approval of FDI.

The results are mixed, with the Hypothesis I being supported by the sign of the coefficients for the size of market and Hypothesis II by the sign of the coefficients associated with skilled labour and good institutions.

All the three explanatory variables included exhibit statistically significant estimated coefficients in WEAK, PROP and APPROV, as shown by the t-statistics. The institutional variable shows no statistical significance in STRONG and REPAT. In this latter case, market size also appears to be not statistically significant. The Chi-squared statistic allow us to reject the null hypothesis that all explanatory variables are jointly not statistically significant in the five regressions at the 1 percent level.

In the case of market size (lnGDP), the negative coefficient supports the view that bigger domestic markets are associated with higher probabilities of imposing restrictions on FDI. Countries with big domestic markets (which include developed but also several developing countries such as China and India) are naturally attractive to MNEs, and they may indeed use FDI as part of a broader industrial policy apparatus. 
The results for the educational attainment variable, EDU, indicate that countries with higher levels of education are less likely to impose restrictions on FDI. This could be indicating that countries with a highly educated labour force would naturally attract FDI in activities intensive in technology and human capital. Thus, there would be no need to impose any sector restrictions on FDI. In addition, as countries with higher levels of education tend to be relatively abundant in capital, the need for imposing limitations on MNEs repatriation of profits and capital would be weaker.

In the equations explaining the absence of weak sector restrictions (WEAK), the absence of property ownership restrictions (PROP) and automatic approval (APPROV), the estimated coefficients for the institutional quality variable (INST) show a positive sign and are statistically significant, indicating that countries with stronger institutions are less likely to impose such restrictions. On the one hand, many countries with strong institutions are OECD members and, as such, must maintain open FDI regimes. On the other hand, the finding lends credence that good institutions and liberal FDI regimes go hand in hand.

The results shown in Table 6 were obtained using binomial logit estimation. These remain almost unchanged using binomial probit estimations. The overall conclusions also hold when using the sample considering only developing countries and transition economies.

\section{Conclusions}

We have succeeded in constructing an ordinal index of FDI policy openness which, however crude, does reveal some interesting facts about recent trends in policies toward FDI. In the first place, there has been a clear liberalizing tendency in FDI regimes throughout the world since 1990.

By 1996, most countries had liberalized their FDI regimes, with FDI liberalization concentrating in Africa, Latin America, and the transition economies. In the case of Latin America, the region has numerous location advantages: some countries have large domestic markets (Argentina, Brazil, Colombia, and Mexico); Mexico, a NAFTA partner, is a good platform for exporting to the United States and Canada; however imperfect a customs union, Brazil and Argentina are partners in MERCOSUR, which enhances their domestic markets, particularly for Argentina; most of them are rich in natural resources. It is then not surprising that FDI flows to Latin America recovered during the 1990s, after the precipitous decline during the so-called "lost decade" of the 1980s. Liberalization has enabled Latin American countries with location advantages to attract considerably larger flows of FDI. Inflows to most of these countries rose sharply during the 1990s [see UNCTAD, 1998: 362-363].

Although the trend toward liberalization continued until 2002, it was less pronounced as compared with the 1990-96 period. Between 1996 and 2002 the increase in the average FDI openness index was statistically significant for all countries, although not for any individual region, except for Africa. In the case of Latin America, the mean and the median in 1996 and 2002 are identical, indicating that FDI liberalization occurred during the first half of the 1990s. 
Both in 1990 and 2002, average FDI openness indices between developing regions were statistically equal, except for the more open regime in Latin America as compared to Asia in 1990. In 1996 Latin America had a significantly more liberal FDI regime than either Africa and developing Asia. By 2002, FDI openness indices in all developing regions were statistically equal to that of developed countries, indicating a process of convergence towards liberal FDI regimes across regions.

The econometric exercise reveals that the location advantages of host countries are the most important factors accounting for differences in FDI inflows. Among location factors, the most important is, first and foremost, the size of the domestic market. The variation of FDI between countries is explained almost exclusively by the absolute level of GDP. In spite of the talk about the internationalization of production and the increasing global market orientation of MNEs, looking at the broad picture, the size of domestic markets still seems to matter most to foreign investors. Other variables that are important are the availability of human resources and growth prospects. Other things being equal, countries with high levels of education attract more FDI than countries with low levels of education. This is also the case in countries with faster growth. The openness of the FDI regime acts as an enabling variable for countries that have significant location assets to offer to prospective foreign investors. It also appears that FDI openness is an aspect of good quality institutions (such as the rule of law, government effectiveness, and regulatory quality). The most significant elements of an open FDI regime, as far as investing companies are concerned, are investorfriendly approval procedures and the absence of strict joint-venture requirements.

The changes in the FDI regime toward greater openness enabled the location advantages of liberalizers to attract larger FDI inflows. In the absence of location advantages, however, liberalization can do little. But these advantages, in particular for the more sophisticated types of FDI in modern manufacturing or services, can be developed. These include improvements in education and technological capabilities. The latter often go hand in hand with vigorous domestic investment. Development policies ought to stress the acquisition of such assets, not only because it will attract foreign investors but mainly because they are the key to development. 


\section{NOTES}

${ }^{1}$ See, for example, UNCTAD [1998: 57].

${ }^{2}$ We interpret the degree of openness as the absence of restrictions.

${ }^{3}$ The education index is a weighted average of the adult literacy rate (two thirds) and the combined gross school enrolment rate (one third).

${ }^{4}$ We did not test for the importance of unskilled labor seeking investment. The reason is that it is not easy to come up with a variable that reflects inter-country differences in unit labor costs that is not inversely correlated with GDP per capita.

${ }^{5}$ The estimated elasticities are statistically different from unity.

${ }^{6}$ This is calculated as the product between the estimated coefficients shown in table 3 and the mean of the educational index in the whole sample, which is 0.75 .

${ }^{7}$ As this variable is not available for 1990, we re-scaled the International Country Risk Guide index (average of control of corruption, law and order, and democratic accountability) comparing its 1996 level with that of the Kaufmann et al index. 


\section{REFERENCES}

Agosin, M. R., and R. Machado, forthcoming, "Economic growth in Central America", Vanishing Growth, The Latin American Experience of the Late Twentieth Century, ed. A. Solimano, Edward Elgar, Northampton, MA.

Agosin, M.R., Barreix, A. and R. Machado (eds), 2005, Recaudar para crecer. Bases para la reforma tributaria en Centroamérica, Washington, D.C., Banco Interamericano de Desarrollo.

Burki, S.J. and G.E. Perry, 1998, Beyond the Washington Consensus: Institutions Matter, Washington, D.C.: World Bank.

Caves, R.E., 1996, Multinational Enterprises and Economic Analysis, Second Edition, New York: Cambridge University Press.

Dunning, J.H., 1981, International Production and the Multinational Enterprise, London: Allen and Unwin.

Dunning, J.H., 1988, Explaining International Production. London: Unwin Hyman.

Hanson, G. H., R. J. Mataloni Jr., and M. J. Slaughter, 2002, "Expansion strategies of U.S. Multinational Firms", Brookings Trade Forum 2001, The Brookings Institution, Washington, D.C.

International Monetary Fund, 1991, Exchange Arrangements and Exchange Restrictions 1990. Washington, D.C.: International Monetary Fund.

International Monetary Fund, 1997, Exchange Arrangements and Exchange Restrictions 1996. Washington, D.C.: International Monetary Fund.

International Monetary Fund, 2003, Exchange Arrangements and Exchange Restrictions 2002. Washington, D.C.: International Monetary Fund.

International Monetary Fund, 2004, International Financial Statistics, Electronic version, Washington, D.C.: International Monetary Fund.

Kaufmann, D., Kraay, A., and M. Mastruzzi, 2003, "Governance matters III: Governance indicators 1996-2002”, World Bank Policy Research Working Papers, 3106, Washington, D.C.: World Bank.

Knack, S., and P. Keefer, 1995, "Institutions and economic performance: Cross-country evidence tests using alternative institutional measures", Economics and Politics, Vol. 7, No.3, pp. 207-227.

UNCTAD, 1998, World Investment Report 1998. Geneva and New York: United Nations. 
UNCTAD, 2003, World Investment Report 2003. Geneva and New York: United Nations.

UNDP, 2002, Human Development Report 2002, New York: United Nations.

World Bank, 2004, World Development Indicators, Electronic version, Washington, D.C.: World Bank.

Yeaple, S. R., 2003a, "The complex integration strategies of multinationals and cross country dependencies in the structure of foreign direct investment", Journal of International Economics, Vol. 60, pp. 293-314.

Yeaple, S. R., 2003b, "The role of skill endowment in the structure of U.S. outward foreign dircct inverstment", The Review of Economics and Statistics, Vol. 85, No. 3, pp. 726-734. 
APPENDIX

COUNTRIES INCLUDED IN EACH GEOGRAPHIC REGION

\begin{tabular}{|c|c|c|c|c|c|}
\hline Africa (28) & & Asia (16) & Latin America (21) & $\begin{array}{c}\text { Transition } \\
\text { economies (21) }\end{array}$ & $\begin{array}{c}\text { Developed } \\
\text { countries (22) }\end{array}$ \\
\hline Algeria & Uganda & Bangladesh & Argentina & Armenia & Australia \\
\hline Angola & Zambia & Cambodia & Bolivia & Azerbaijan & Austria \\
\hline Benin & Zimbawe & China & Brazil & Belarus & Belgium \\
\hline Burkina Faso & & Hong Kong & Chile & Bulgaria & Canada \\
\hline Cameroon & & India & Colombia & Croatia & Denmark \\
\hline Central African Rep. & & Indonesia & Costa Rica & Czech Republic & Finland \\
\hline Chad & & Korea, Rep. of & Dominican Republic & Estonia & France \\
\hline Congo & & Malaysia & Ecuador & Hungary & Germany \\
\hline Côte d' Ivore & Middle East (3) & Nepal & El Salvador & Latvia & Greece \\
\hline Egypt & & Pakistan & Guatemala & Lithuania & Ireland \\
\hline Ethiopia & Lebanon & Philippines & Haiti & Moldova & Israel \\
\hline Gabon & Syrian Arab Rep. & Singapore & Honduras & Mongolia & Italy \\
\hline Ghana & Yemen, Rep. of & Sri Lanka & Jamaica & Poland & Japan \\
\hline Guinea & & Thailand & Mexico & Romania & Netherlands \\
\hline Kenya & & Turkey & Nicaragua & Russian Fed. & New Zealand \\
\hline Lesotho & & Viet Nam & Panama & Slovakia & Norway \\
\hline Madagascar & & & Paraguay & Slovenia & Portugal \\
\hline Mauritius & & & Peru & Tajikistan & Spain \\
\hline Mozambique & & & Trinidad and Tobago & Turkmenistan & Sweden \\
\hline Namíbia & & & Uruguay & Ukraine & Switzerland \\
\hline Nigeria & & & Venezuela & Uzbekistan & United Kingdom \\
\hline Senegal & & & & & United States \\
\hline South África & & & & & \\
\hline Togo & & & & & \\
\hline Tunísia & & & & & \\
\hline
\end{tabular}

